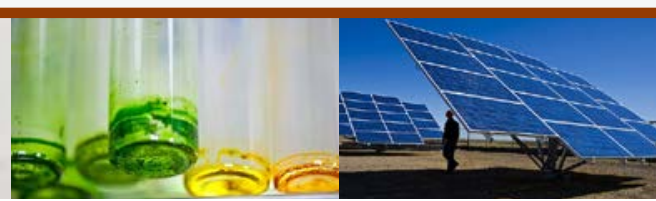

Energy Analysis

\title{
International Trade of Wood Pellets
}

\section{Market Overview}

The production of wood pellets has increased dramatically in recent years due in large part to aggressive emissions policy in the European Union (EU); however, the market is still small and fraught with uncertainty as the international trade of wood pellets increases.

Advantages of wood pellets include (1) the main feedstock, which is wood waste from primary and secondary saw mills, and (2) the high energy density and consistency of the fuel, which allows international trade to be feasible (Junginger et al. 2008). Concerns about greenhouse gas (GHG) emissions have piqued interest in the use of wood pellets as an alternative to fossil fuel sources for boilers as well as electricity generation (Spelter and Toth 2009).

Currently, the majority of demand for wood pellets originates from the EU, with particular interest in Nordic countries (Hillring 2006). Major exporters are the United States and Canada, although Russia and parts of Asia and South America have potential to become exporting markets. In addition to the possibility of other exporters, policy and economic factors have a large impact on the trade of wood pellets. Figure 1 shows a high-level influence diagram highlighting many of the dynamics involved with the wood pellet market, using the United States as an example.

Historically, wood waste, such as pulp and sawdust, has been (1) used for energy within the wood product plants or for local municipalities, (2) disposed of in landfills, or (3) exported, especially to Japan (Hillring 2006). The supply of wood waste is driven by the demand for wood-based products, such as paper and lumber, rather than the demand for wood pellets (Spelter and Toth 2009). In times of low wood-waste supplies, as was the case in 2008, some facilities have resorted to using roundwood and other higher-quality wood sources to produce wood pellets.

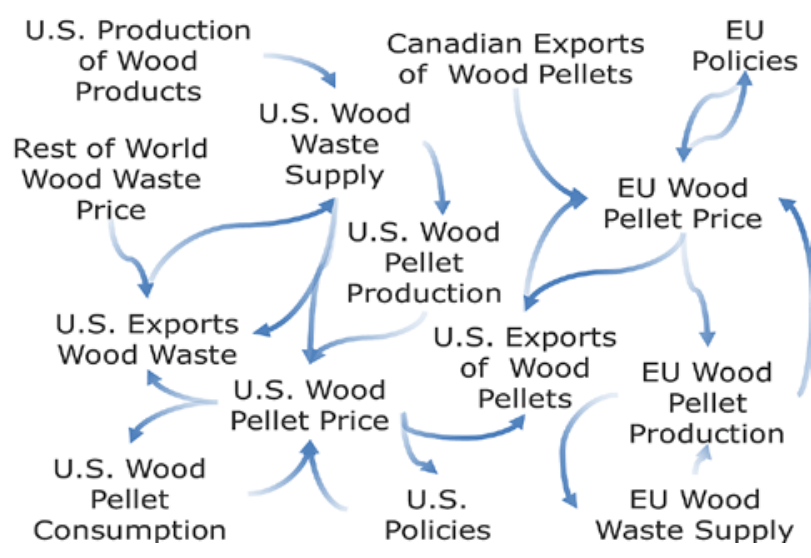

Figure 1. Influence diagram for U.S. wood pellet trade

Tracking the trade of wood pellets internationally is cumbersome; trade statistics combine sawdust, wood waste, and wood scrap, whether or not agglomerated in logs, briquettes, pellets, or similar forms, into one category. Fortunately, a new code for wood pellets (4401.31.0000) was added in 2012 to the Harmonized Commodity Description and Coding System, which is the international standard for trade nomenclature administered by the World Customs Organization; this change may lead to more consistency in international trade data for pellets among the United States and other countries' trade agencies (Lamers et al. 2012). Quantities of biomass traded for energy use are also obscured by countries that export forest products or agricultural products, which could be used for energy production, but the final end use is unknown at the time of export (Heinimo and Junginger 2009).

The following sections detail the wood pellet market from the perspective of major participating countries. 
Figure 2. Destination of wood pellets produced in the United States and Canada in 2008 (Spelter and Toth 2009)

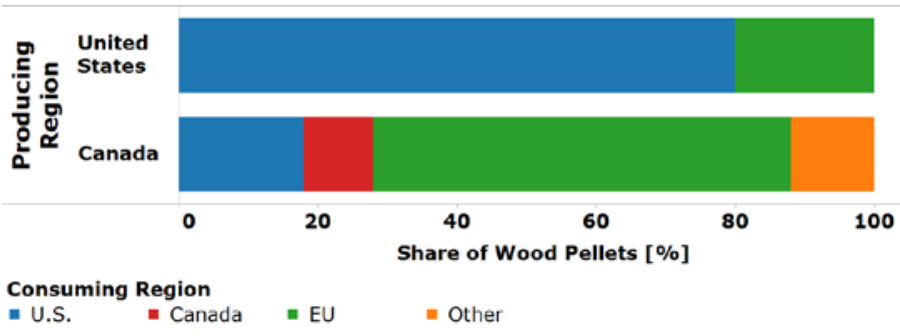

Figure 3. Wood pellet production capacity in the United States by region (Spelter and Toth 2009)

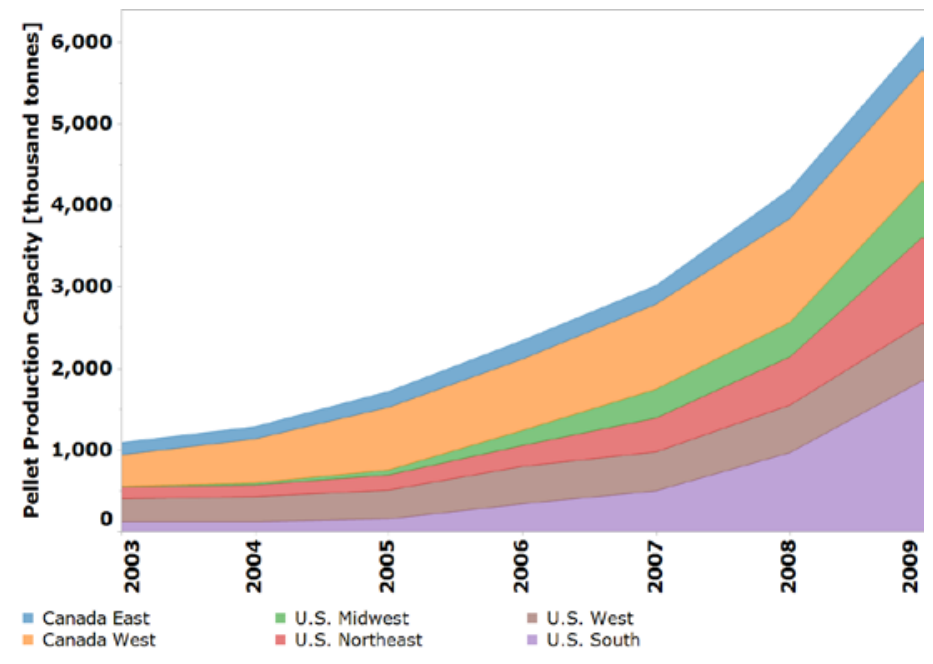

Figure 4. U.S. exports of wood waste (2000-2008) and wood pellets to the EU (2009-2011) (Eurostat 2012)

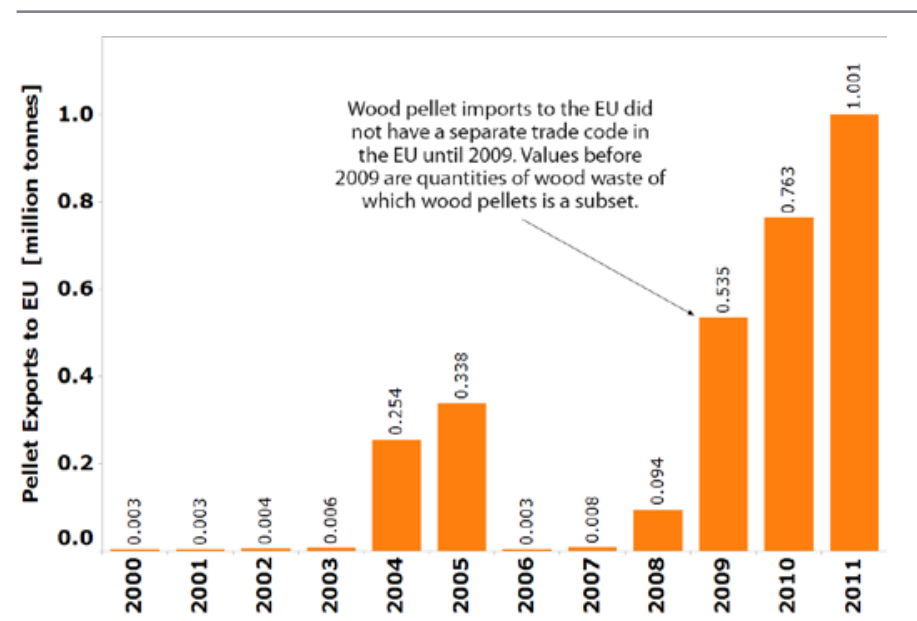

\section{United States}

Wood pellet production in the United States has only recently focused on the export market; in 2008, almost $80 \%$ of wood pellets were used domestically, which contrasts strikingly with Canada, the other major exporter of wood pellets, which consumed only about $10 \%$ domestically. A comparison of the destination for wood pellets produced in the United States and Canada is shown in Figure 2. The majority of all exports from both the United States and Canada go to the EU.

The capacity for pellet production has increased dramatically in recent years in the United States with most of the increase attributed to growing demand in the EU, as is shown in Figure 3. The southern region has experienced especially large growth due to its availability of wood resources and proximity to the EU (Spelter and Toth 2009).

Historical wood pellet trade data are difficult to find because there was a lack of uniform customs nomenclature for wood pellets until 2012. The EU created a separate trade category for wood pellets in 2009, while the United States traded wood pellets under the code for wood waste and scrap. The U.S. International Trade Commission's and the Eurostat's data for exports of wood pellets and wood waste from the United States to the EU disagree dramatically and show contrasting trends; however, the U.S. International Trade Commission's data are most likely under-representing exports of wood pellets and wood waste due to U.S. exporters reporting wood pellet trade under incorrect trade codes (Goetzl 2012).

Figure 4 shows the export data of wood waste and wood pellets to the EU from the United States according to Eurostat. These data show a large increase in wood pellet exports after 2008 as U.S. companies have entered the market to help satisfy increased wood pellet demand in Europe. Historically, the United States imported large quantities of wood pellets from Canada (see Figure 6), but these imports have almost stopped due to the increase in domestic production.

In terms of raw materials, most years the United States has an abundance of wood waste supplies; however, the recent recession (and concurrent downturn in the construction industry) has caused the supply of wood waste to come close to the demand for wood waste for pellets, fiberboard, pulp, and particleboard (Spelter and Toth 2009). The comparison of the supply of wood waste and pulp to the demand for these products from end users is shown in Figure 5. With limited supplies of cheap wood residues, some plants have turned to roundwood and other higher-quality wood resources to make their wood pellets (Spelter and Toth 2009). 


\section{Canada}

Canada's abundant wood resources and manufactured wood products are strong advantages that have led to a vibrant wood pellet industry. Canada is currently the largest exporting country. As is shown in Figure 2, the production of wood pellets is geared primarily for export. Figure 6 illustrates that production quantities have increased to around 1.32 million tonnes, with the majority of that being exported overseas (Lamers et al.

2012). Canada consumes very little domestically compared to its production and imports close to zero wood pellets. Historically, Canada exported significant quantities of wood pellets to the United States; however, with the expansion of the capacity for wood pellet production in the United States, that quantity dwindled to only 40 kilotonnes in 2010.

\section{European Union}

The EU is the main consumer of wood pellets as well as a major producer. There is a high volume of wood pellet trade among EU member countries. As shown in Figure 7, the EU has a much larger wood pellet production than the United States or Canada but still requires imports of wood pellets in order to satisfy the demand (Lamers et al. 2012).

Policies around GHG emissions, especially the Renewable Energy Directive (RED), have caused increases in wood pellet consumption, particularly in Nordic countries (Lamers et al. 2012). RED requires that $20 \%$ of total production of energy come from renewable sources by 2020 with specific requirements for each individual country (Kittler et al. 2012). To reach their goals, Nordic countries have chosen wood pellets in district heating and electricity generation due to wood availability and their traditional preference to use wood for energy. Despite large forest reserves and high levels of wood pellet production, they still need to import wood pellets in order to meet demand. Scandinavia and Austria have developed strong national markets due to the presence of long-standing forestry and wood processing industries as well as robust domestic bioenergy policies (Lamers et al. 2012).

Recently, the European Commission proposed implementing standards for sustainability of wood pellets consumed in the EU, which has the potential to affect international trade. Although RED defines sustainability criteria for liquid biofuels, there is not a standard for solid biofuels. In 2010, the EU decided against setting a required standard for sustainability of solid biomass but suggested that individual countries develop their own standards (Kittler et al. 2012). The EU outlined the following minimum standards for countries to consider:
Figure 5. North American wood residue supply and demand from pellets, medium-density fiberboard, pulp, and particleboard (Spelter and Toth 2009)

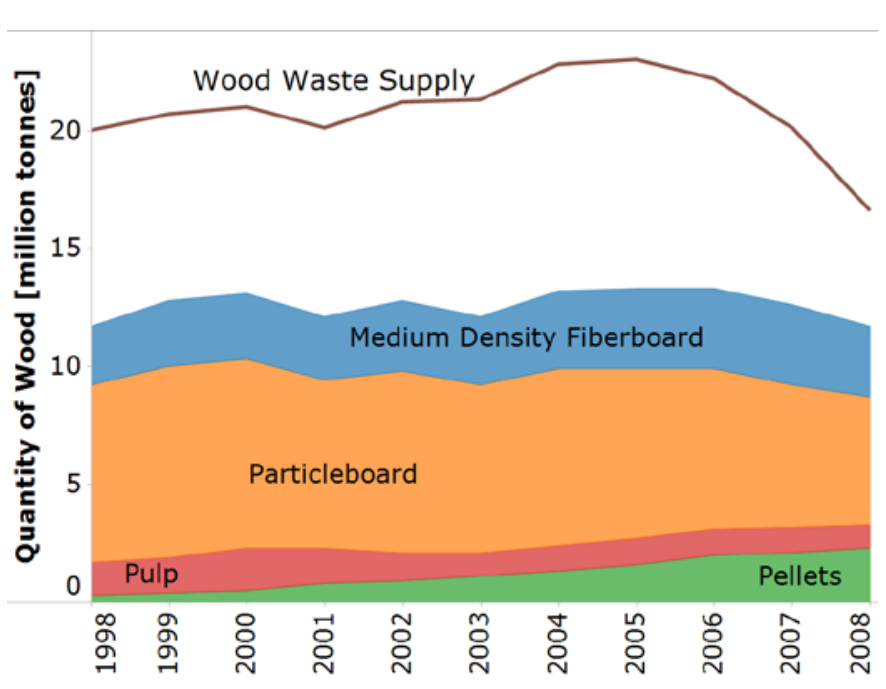

Figure 6. Canadian wood pellet trade balance 2000-2010 (Lamers et al. 2012)

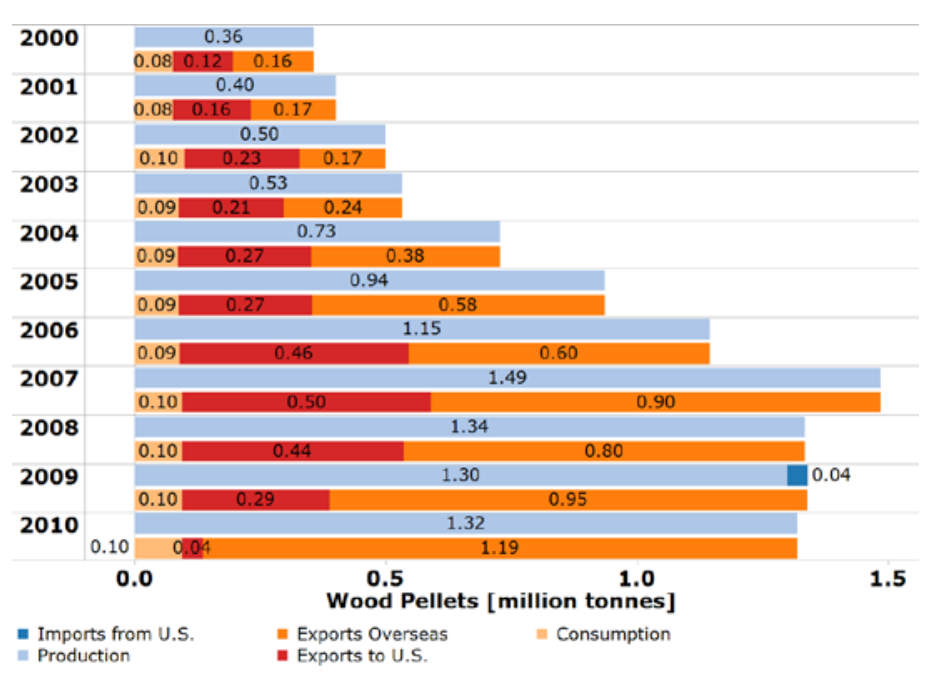

- Prohibiting the collection of biomass from land converted from forest, carbon stock areas, or land with high biodiversity

- Requiring the use of a common GHG calculation methodology to ensure that GHG savings are at least $35 \%$ initially and rise to $60 \%$ by 2018 for new installations

- Favoring the installation of plants with high energy conversion efficiencies

- Monitoring the origin of biomass. 
In 2011, the EU began to reevaluate creating binding EUwide policies due to large discrepancies and uncertainty in sustainability standards among member countries (Kittler et al. 2012). The International Standards Organization is also working on establishing sustainability certification for solid biomass, which will help solidify requirements. Any sustainability requirements are expected to focus on the origin, transportation, and production of wood pellets. The decision to have or not have binding EU standards will have a large impact on the potential for U.S. wood pellet exports because some feedstocks will be ineligible and longer transportation distances may have higher carbon footprints than EU-based resources. However, a more universal standard will reduce the complexity caused by the 44 different national and international systems and initiatives that address sustainability (Kittler et al. 2012).

\section{Russia}

Despite abundant forestry resources, Russia has not been a significant exporter of wood pellets. Russia has a small wood pellet industry, which serves a growing domestic market and is primarily located in the northwestern and central areas of the country (where there is an established wood products market). Around $10-15 \%$ of production is consumed domestically, while the majority of the remaining production is exported to the EU through ports in St. Petersburg. Russia's nominal wood pellet capacity in 2007 was on the order of 1.2 million tons, for instance (Junginger 2009). The low production of wood pellets is possibly due to the minimal investment in bioenergy and lack of a comprehensive energy plan with policies aimed at bioenergy. The abundance and availability of fossil fuel sources has likely outcompeted development of alternative energy sources. However, Russia could have a large influence on wood pellet trade in the EU due to its geographic proximity and its wealth of forests (Lamers et al. 2012).

\section{Other Regions}

The availability of wood resources, the growing timber industries, and increasing energy demand in Asia and Latin America could lead to significant growth in the production, consumption, and trade of wood pellets. For most countries in these regions, wood pellet production is in its infancy, and reports on production facilities and capacities are extremely sparse; however, the potential for these emerging markets to produce and consume wood pellets means that they could greatly affect international wood pellet trade (Cocchi et al. 2011).
Figure 7. EU external wood pellet trade balance 2000-2010 (Lamers et al. 2012)

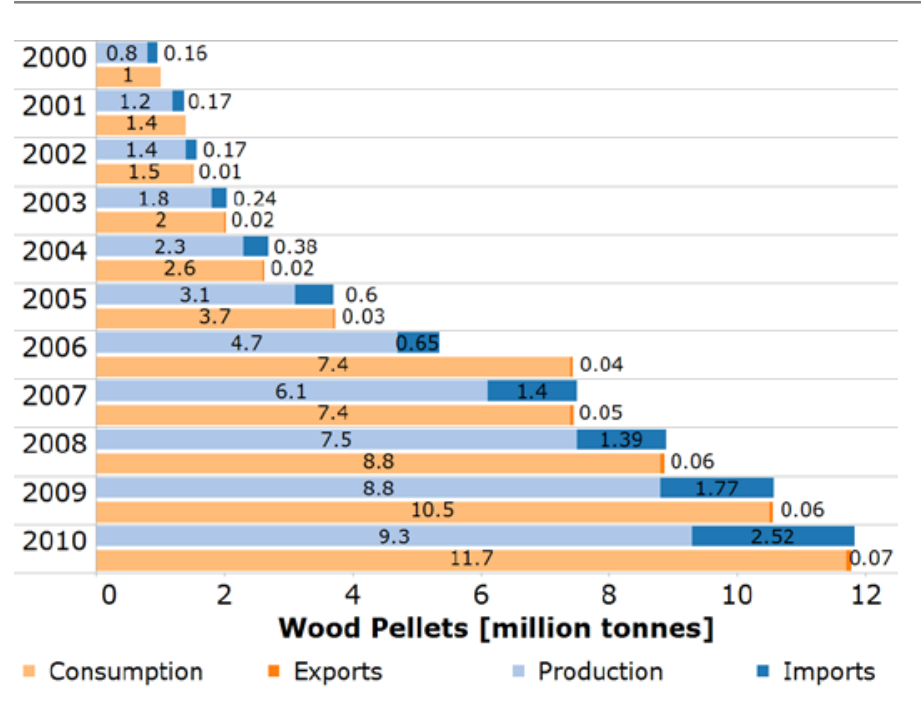

Japan is the largest consumer of wood pellets in Asia, and due to its lack of domestic wood resources, imports twice as much as it produces. Japanese imports of wood pellets are expected to continue growing to increase co-firing of biomass in coal-fired power plants.

South Korea has also begun to consume increasing amounts of wood pellets as part of its plan to reduce carbon dioxide emissions by $30 \%$ by 2020 .

South Korea's wood pellet production potential is limited to approximately 1 million tonnes of domestic wood pellet consumption and would require imports to meet projected demand for wood pellets (Cocci et al. 2011). Other countries in Asia may follow.

Latin American countries are seen as a large potential source of wood pellets, and this industry is expected to develop as more wood resources are utilized. Growing energy consumption could also cause more consumption of wood pellets in this region.

\section{Prices}

There are relatively few price indices for wood pellets in the EU; the few that do exist run into the issue that many of the market participants do not participate in pellet price surveys. Sikkema et al. (2011) profile industrial pellet prices for the two countries with the largest markets: the Netherlands and Sweden. Cost, Insurance, and Freight (CIF) prices for bulk pellets in the Netherlands increased from $€ 115 /$ tonne in mid-2007 to $€ 140 /$ tonne in early-2009 but consistently decreased during 2010, ending the year at $€ 125 /$ tonne. Prices in Sweden are generally 
Figure 8. Residential wood pellet prices by year in select European countries (FORCE Technology)

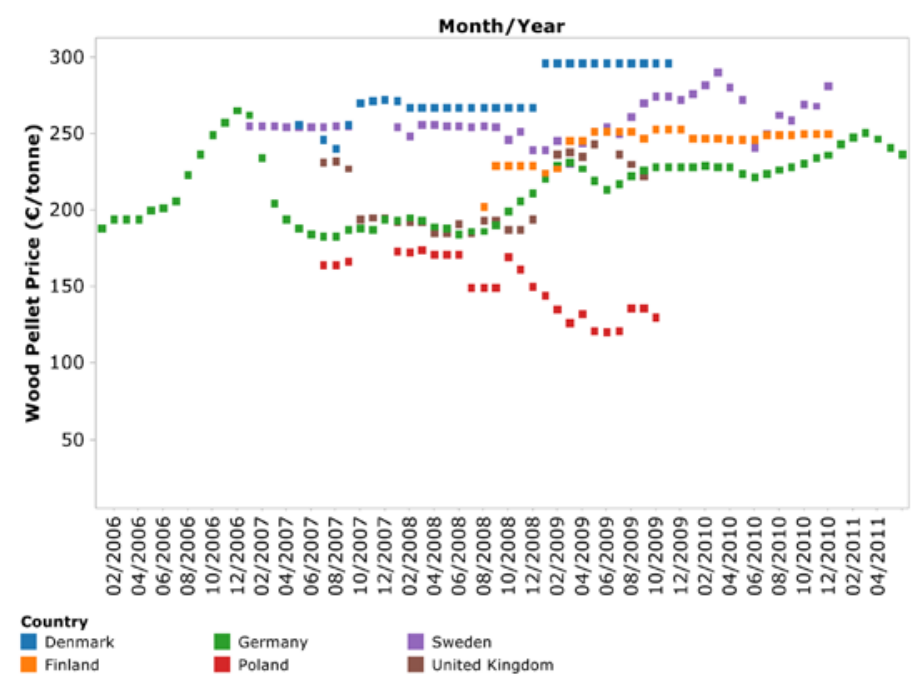

more consistent but did increase some from 2007, at $€ 125 /$ tonne, to 2010 , ending at around $€ 138$ /tonne. The prices in these two countries are moving in opposite directions, most likely due to different methodologies in price setting: the Dutch price is from an index published by APX-Endex (www.apxendex.com) whereas Nordic prices come from FOEX ( $w w w$ foex.fi).

Residential pellet prices in the EU also vary by region (see Figure 8), but they are generally higher than those for industrial pellets. In countries that do not use the Euro, such as Sweden and the United Kingdom, the price can also be variable due to the exchange rate. Much of the variation among different EU countries is explained by differences in national policies, demands, and supplies (WIP Renewable Energies 2009). For example, Poland mostly exports its wood pellet supply, keeping domestic prices low, whereas Sweden has a strong demand for pellets.

Transportation is a major component of wood pellet prices. Within the EU, most pellets are transported via truck; costs ranged from $€ 12 /$ tonne to $€ 18 /$ tonne in 2009 (Sikkema et al. 2011). For example, a specific shipment of 25 tonnes cost $€ 12 /$ tonne when it was shipped $200 \mathrm{~km}$. Imports from Russia generally arrive using short sea shipping (4000- to 5000-tonne loads) whereas those from North America are delivered in Panamax ocean vessels $(60,000$ - to 80,000 -tonne loads). The majority of pellets are shipped under long-term contracts, which are usually more expensive than short-term contracts because buyers pay a premium for supply security. Freight costs between North America and the EU ranged from $€ 27 /$ tonne to $€ 69 /$ tonne between 2002 and 2010; freight costs from Russia were between $€ 20 /$ tonne and $€ 25 /$ tonne in 2009. Free on Board (FOB) prices for wood pellets from North America ranged from $€ 78 /$ tonne in 2009 to $€ 112 /$ tonne in 2010. Prices from Russia ranged from $€ 105 /$ tonne to $€ 119 /$ tonne (FOB).

Total wood pellet export costs were estimated to be around \$180/short ton in 2012 for both the southern United States and Canada (Walker 2012). These costs include wood, labor, energy, depreciation plus interest, overhead, transportation to the port, loading, ocean freight, and other costs. U.S. domestic wholesale FOB pellet prices in the 2011-2012 timeframe ranged from $\$ 160 /$ short ton to $\$ 179 /$ short ton in the Northeast to $\$ 143 /$ short ton to $\$ 161 /$ short ton in the South. Whether exporting wood pellets to the EU remains profitable depends on many factors, but the exchange rate between the Euro and the dollar will play an important role.

\section{Conclusion}

Rapid growth in international wood pellet trade is expected to continue to satisfy GHG emissions policies. The major developments have been in North America and Europe, but new producing and consuming regions could enter the market, which would expand the current trade quantities and routes. The United States appears poised to increase exports further with continued construction of new production plants in the Southeast and by turning to wood sources beyond wood waste. However, energy policies especially in the EU and wood pellet production growth in countries with vast forestlands and established forest industries could compete with U.S. wood pellet-export potential.

\section{References}

Cocchi, M.; Nikolaisen, L.; Junginger, M.; Goh, C. S.; Heinimo, J.; Bradley, D.; Hess, R.; Jacobson, J.; Ovard, L.; Thran, D.; Hennig, C.; Deutmeyer, M.; Schouwenberg, P.; Marchal, D. (2011). Global Wood Pellet Industry Market and Trade Study. IEA Bioenergy Task 40. Accessed October 7, 2012: www.bioenergytrade.org/mobile/640/downloads/t40-globalwood-pellet-market-study final.pdf.

Development and Promotion of a Transparent European Pellets Market; Creation of a European Real-time Pellets Atlas. Munich, Germany: WIP Renewable Energies, December 2009. Eurostat. (2012). "EU Trade Since 1995 by CN8." Statistics Database. Brussels: The European Commission. Accessed on October 7, 2012: http://epp.eurostat.ec.europa.eu. 
FORCE Technology. (undated). “Pellet Market Data.” Pelletsatlas. Accessed April 2, 2013. www.pelletsatlas.info/cms/site.aspx? $p=9138$.

Goetzl, A. (2012). Pellet Power - Global Trade in Wood Pellets. Washington, D.C.: U.S. International Trade Commission. Accessed October 2, 2012: www.usitc.gov/ publications/332/executive_briefings/EBOT_Wood_Pellets_Final.pdf.

Heinimo, J.; Junginer, M. (2009). "Production and Trading of Biomass for Energy - An Overview of the Global Status." Biomass and Bioenergy. (33:9); pp. 1310-1320.

Hillring, B. (2006). "World Trade in Forest Products and Wood Fuel.” Biomass and Bioenergy. (30:10); pp. 815-825.

Junginger, M.; Bokesjø, T.; Bradley, D.; Dolzan, P.; Faaij, A.; Heinimo, J.; Hektor, B.; Leistad, Ø.; Ling, E.; Perry, M.; Piacente, E.; Rosillo-Calle, F.; Ryckmans, Y.; Schouwenberg, P.; Solberg, B.; Trømborg, E.; da Silva Walter, A.; de Wit, M. (2008). "Developments in International Bioenergy Trade." Biomass and Bioenergy. (32:8); pp. 717-729.

Junginger, M.; Sikkema, R.; Faaij, A.; Bukvić, A.; Melin, S.; Ovsyanko, A.; Rakitova, O. (2009). Analysis of the Global Pellet Market Including Major Driving Forces and Possible Technical and Non-technical Barriers. Utrecht, The Netherlands: Intelligent Energy Europe. Accessed October 2, 2012: www.pelletsatlas.info/pelletsatlas_docs/ showdoc.asp? id=090316152328\&type $=$ doc\&pdf=true.

Kittler, B.; Price, W.; McDow, W.; Larson, B. (2012). Pathways to Sustainability: An Evaluation of Forestry Programs to Meet European Biomass Supply Chain Requirements. Pinochet Institute. Accessed September 17, 2012: www.edf.org/sites/default/files/ pathwaysToSustainability.pdf.

Lamers, P.; Junginger, M.; Hamelinck, C.; Faaij, A. (2012). "Developments in International Solid Biofuels Trade - An Analysis of Volumes, Policies, and Market Factors." Renewable and Sustainable Energy Reviews (15:6); pp. 2655-2676.

Sikkema, R.; Steiner, M.; Junginger, M.; Hiegl, W.; Hansen, M.; Faaij, A. (2011).

"The European Wood Pellet Markets: Current Status and Prospects for 2020." Biofuels, Bioproducts and Biorefining (5:3); pp. 250-278.

Spelter, H.; Toth, D. (2009). "North American Wood Pellets Sector.” Research Paper FPL-RP-656. Madison, WI: U.S. Department of Agriculture, Forest Service, Forest Products Laboratory, $21 \mathrm{pp}$.

Walker, S. (July 2012). "Report: Outlook for the Pellet Fuels Industry." Presented at the Pellet Fuels Institute Annual Conference. Accessed April 3, 2013: http://pelletheat.org/ wp-content/uploads/2010/01/Walker.pdf.

WIP Renewable Energies, Hiegl, W.; Janssen, R.(2009). "Development and Promotion of a Transparent European Pellets Market; Creation of a European Real-Time Pellets Atlas." Vienna, Austria: Intelligent Energy Europe, 54 pp.

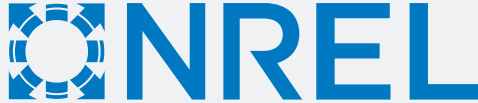 \\ NATIONAL RENEWABLE ENERGY LABORATORY}

This fact sheet was completed

by analysts in NREL's

Strategic Energy Analysis

Center (SEAC). NREL and

SEAC conduct a broad

range of energy analysis in

support of NREL programs

and initiatives, DOE's Office

of Energy Efficiency and

Renewable Energy (EERE),

technology transfer, and

the greater energy analysis

community. With offices

in Washington, D.C., and

Golden, Colorado, SEAC

promotes understanding

and collaboration through

partnerships, publications,

conferences and seminars,

and various online resources.

National Renewable Energy Laboratory 15013 Denver West Parkway Golden, C0 80401

303-275-3000 • www.nrel.gov

NREL is a national laboratory of the U.S. Department of Energy, Office of Energy Efficiency and Renewable Energy, operated by the Alliance for Sustainable Energy, LLC.

NREL/BR-6A20-56791・May 2013

Photos credits (page 1, left to right): iStock 13737597; Pat Corkery, NREL 16374; iStock 12123595; Toyota Motor Sales, USA, NREL 16933; Dennis Schroder, NREL 18229; Dennis Schroeder, NREL 19163

Printed with a renewable-source ink on paper containing at least $50 \%$ wastepaper, including $10 \%$ post consumer waste. 